\title{
Levels of Polycyclic Aromatic Hydrocarbons, Polychlorinated Biphenyls, and Organochlorine Pesticides in Various Tissues of White-Backed Vulture in India
}

\author{
V. Dhananjayan ${ }^{1,2}$ and S. Muralidharan ${ }^{1}$ \\ ${ }^{1}$ Sálim Ali Centre for Ornithology and Natural History (SACON), Anaikatty, Coimbatore 641108, India \\ ${ }^{2}$ Industrial Hygiene \& Toxicology Division, Regional Occupational Health Centre (Southern), ICMR Complex, \\ Kannamangala PO, Devanahalli TK, Bangalore 562 110, India
}

Correspondence should be addressed to V. Dhananjayan; dhananjayan_v@yahoo.com

Received 3 April 2013; Accepted 20 June 2013

Academic Editor: Qaisar Mahmood

Copyright (C) 2013 V. Dhananjayan and S. Muralidharan. This is an open access article distributed under the Creative Commons Attribution License, which permits unrestricted use, distribution, and reproduction in any medium, provided the original work is properly cited.

\begin{abstract}
This study provides information on the current status of contamination by polycyclic aromatic hydrocarbons (PAHs), polychlorinated biphenyls (PCBs), and organochlorine pesticides (OCPs) in the tissues of endangered White-backed Vulture Gyps bengalensis in India. Chemical analyses revealed detectable amounts of PAHs, PCBs, and OCPs. Concentration ranges of $\sum$ PAHs, $\sum$ PCBs, and $\sum$ OCPs in tissues were 60-2037 ng/g, 30-5790 ng/g, and 3.2-5836 ng/g wet weight, respectively. 1,1-Dichloro-2,2-bis(pchlorophenyl)ethylene ( $p, p^{\prime}$-DDE) concentrations ranged from below detectable level to $599 \mathrm{ng} / \mathrm{g}$ wet weight, representing more than $90 \%$ of the total dichlorodiphenyltrichloroethane (DDT). Among the various OCPs analyzed, $p, p^{\prime}$-DDE was detected most frequently. All the contaminants recorded show higher accumulation in liver than other tissues. Levels of contaminants measured in the tissues of vulture are comparable with the levels documented in a number of avian species and are lower than those reported to have caused deleterious effects. Although no threat is expected from the current level of contamination, the presence of varying levels of contaminants and their additive or synergistic toxicity is a cause of concern to vultures. Values reported in this study can serve as guideline for future research.
\end{abstract}

\section{Introduction}

Polycyclic aromatic hydrocarbons (PAHs), polychlorinated biphenyls (PCBs), and organochlorine pesticides (OCPs) are of great concern as environmental contaminants due to their persistence, lipophilicity, bioaccumulative nature $[1,2]$, tendency to concentrate in wildlife through food chain $[2$, $3]$, and profound consequences by way of increased reproductive dysfunction [4], increased susceptibility to diseases or other stresses, and changes in normal behavior patterns [5]. PAHs are ubiquitous environmental contaminants with high toxicity and potential carcinogenicity. As a consequence, environmental contamination by PAHs has steadily increased in recent years [6]. Although the PAHs are rapidly metabolized in birds [7], the residues of parent PAHs have been detected in bird tissues in relation to the source of combustion [8] and petroleum [4]. It has been established that an association exists between wild birds, especially birds of prey, and persistent chemical pollutants in the environment [9]. PCBs and OCPs are ubiquitous contaminants in the global environment due to their persistence and lipophilicity; they accumulate in the lipid tissues of organisms [10]. The most affected species are those which feed on contaminated food, causing population declines through long-term reproductive depression and acute poisoning [11]. Organochlorines such as hexachlorocyclohexane $(\mathrm{HCH})$ and DDT still account for two-thirds of the total consumption in the country for agriculture and public health purposes, respectively [12]. Although the use of organochlorine pesticides and PCBs is restricted in India, their usage is allowed for specific purposes.

White-backed Vulture Gyps bengalensis was regarded as the possible commonest large raptor in the world during 1985 [13]. They feed on carcasses, often in large flocks. Indeed 
TABLE 1: Details of White-backed Vulture received from Ahmedabad, India.

\begin{tabular}{lcccr}
\hline S. no. & Date of collection & Location & No. of individuals & Weight (range) $(\mathrm{kg})$ \\
\hline 1 & January 2005 & Ahmedabad & $5(3 \mathrm{M}, 2 \mathrm{~F})$ & $5.55-6.27$ \\
2 & January 2006 & Ahmedabad & $3(1 \mathrm{M}, 2 \mathrm{~F})$ & $3.14-4.95$ \\
3 & January 2007 & Ahmedabad & $7(3 \mathrm{M}, 4 \mathrm{~F})$ & $4.01-6.03$ \\
\hline
\end{tabular}

the number of $G$. bengalensis was considered unnaturally high because of the abundant availability of animal carcasses around human habitation in India. Prakash et al. [14] reported a decline in the population of White-backed Vulture up to $95 \%$ in its entire known distribution ranges in India during the last ten years. While Cunningham et al. [15] reported that the most likely cause of vulture decline was a novel infectious disease, Pain et al. [16] said that although there could be more than one factor responsible for such a mysterious situation, the role played by contaminants cannot be entirely ruled out. When the real reason for the vulture mortality across the country and neighbourhood continued to be elusive, Oaks et al. [17] demonstrated that the diclofenac, an anti-inflammatory drug used for treating cattle, was responsible for vulture mortality. Nevertheless, information on the residue levels of persistent contaminants, namely, PAHs, PCBs, and OCPs in vulture is necessary as they have the potential to cause mortality and population decline in birds.

Vultures, by virtue of their position at the top of the food chain, accumulate contaminants in their tissues and thus serve as sensitive indicators of environmental contamination [2]. Attention of conservationists has been on the vulnerability of birds of prey to organochlorine contaminants. Dhananjayan et al. [18] reported OCP residues in blood plasma of three species of vulture in India. It was also reported that secondary exposure to insecticide residues through feeding on contaminated carcasses is likely to be a major threat to some vulture species [19]. The objective of this study was to determine the levels of PAHs, PCBs, and OCPs in various tissues of vultures. Since there is not much information available on the residue levels of these contaminants in the tissues of vultures in India, data generated through this exercise is expected to serve as reference values.

\section{Methods}

2.1. Study Area and Sample Collection. Fifteen White-backed Vultures which succumbed to kite injuries in Ahmedabad $\left(23^{\circ} 03.00^{\prime} \mathrm{N}\right.$ to $\left.72^{\circ} 58.00^{\prime} \mathrm{E}\right)$, Gujarat, were collected between January 2005 and January 2007 (Table 1). Ahmedabad is one of the cities where steel and petrochemical industries are many. Recent studies have reported prevalence of organochlorine chemical residues in blood and tissues samples of various species of birds collected in this region $[18,20-22]$. Similar to the national scenario, there was a steep decline in vulture population in Gujarat between 2005 and 2007, according to surveys carried out by the Ministry of State for Environment and Forests [23]. It may be noted that people fly kites as an entertainment during a festival called Uttarayan which falls in January every year. While birds in thousands get injured, they die in hundreds. Samples were collected with the help of Gujarat State Forest Department and Animal Help Foundation, Ahmedabad, on opportunistic basis. Tissues or the whole carcass was air lifted to the laboratory at Coimbatore depending on the condition of the birds. Tissues, namely, brain, liver, and muscle were separated and stored in deep freezer in clean polythene vials till the time of processing.

2.2. Processing and Analysis of Samples for PAHs. Tissue samples $(5-10 \mathrm{~g})$ were digested in $6 \mathrm{~N}$ potassium hydroxide for $24 \mathrm{~h}$ at $35^{\circ} \mathrm{C}$. Digestate was cooled and then neutralized with glacial acetic acid. The mixture was then extracted three times with methylene chloride, and the extracts were combined and concentrated to near dryness before reconstituting in petroleum ether for transfer to a $20 \mathrm{~g} 1 \%$ deactivated silica gel column topped with $5 \mathrm{~g}$ neutral alumina. PAHs were eluted using $100 \mathrm{~mL} 40 \%$ methylene chloride/ $60 \%$ petroleum ether followed by $50 \mathrm{~mL}$ methylene chloride. The eluants were concentrated using rotary flask evaporator to near dryness and redissolved in $2 \mathrm{~mL}$ acetonitrile. All the samples were transferred into HPLC autosampler vials for PAHs analysis as per the method followed by $\mathrm{Hu}$ et al. [24, 25]. All the samples were quantified for 15 components of PAHs, namely, naphthalene, acenaphthene, fluorene, phenanthrene, anthracene, fluoranthene, pyrene, benz(a)anthracene, chrysene, benzo[b]fluoranthene, benzo $(k)$ fluoranthene, benzo( $a)$ pyrene, dibenz $(a, h)$ anthracene, benzo $(g, h, i)$ perylene, and indeno(1,2,3-cd)pyrene using Agilent 1100 HPLC system equipped with programmable fluorescence detection at excited and emission wavelength of 260 and $500 \mathrm{~nm}$, respectively. About $10 \mu \mathrm{L}$ of the sample was injected through an autosampler into $\mathrm{C} 18$ column (Zorbax $4.6 \times 250 \mathrm{~mm}$ ) of $5 \mu \mathrm{m}$ particle size. The temperature of the column was maintained at $20^{\circ} \mathrm{C}$. Water/acetonitrile (ACN) was used as a mobile phase with a flow of $1 \mathrm{~mL} / \mathrm{min}$. The initial content of ACN was $50 \%$ and then increased into $60 \%(0-3 \mathrm{~min})$ and $95 \%(3-14 \mathrm{~min})$. This level was held constant for $24 \mathrm{~min}$ until the end of the analysis. All the results were compared with external PAHs mixture standard (AccuStandard, USA). Minimum detection limits for PAHs ranged from 3 to $10 \mathrm{ng} / \mathrm{g}$ wet weight depending on the compound. The number of spikes, duplicates, and blanks was $9 \%$ of the total number of samples analyzed. The recovery of the compounds from fortified samples $(100 \mathrm{ng} / \mathrm{g})$ ranged between $78 \%$ and $103 \%$. Concentrations were not adjusted for per cent recovery.

2.3. Processing and Analysis of Samples for PCBs and OCPs. Tissues (5-10 g) were homogenized with anhydrous sodium 
TABLE 2: PAH residues (ng/g wet wt) detected in various tissues of vultures in India.

\begin{tabular}{|c|c|c|c|c|c|c|c|c|c|c|}
\hline \multirow[t]{2}{*}{ PAHs } & & \multicolumn{3}{|c|}{ Brain $(n=15)$} & \multicolumn{3}{|c|}{ Liver $(n=15)$} & \multicolumn{3}{|c|}{$\begin{array}{c}\text { Muscle }(n=15) \\
\text { Lipid weight }(\%) 11\end{array}$} \\
\hline & & Mean & Range & $\%$ & Mean & Range & $\%$ & Mean & Range & $\%$ \\
\hline Naphthalene & Nap & 53.2 & ND-246 & 47 & 180 & ND-881 & 53 & 29.0 & ND-123 & 33 \\
\hline Acenaphthene & Acnp & 46.4 & ND-212 & 60 & ND & ND & 0 & ND & ND & 0 \\
\hline Fluorene & Flu & ND & ND & 0 & ND & ND & 0 & 11.8 & ND-39 & 27 \\
\hline Fluoranthene & Flur & ND & ND & 0 & ND & ND & 0 & 32.8 & ND-144 & 40 \\
\hline Pyrene & Pyr & 7.4 & ND-17 & 47 & ND & ND & 0 & ND & ND & 0 \\
\hline $\operatorname{Benz}(a)$ anthracene & Bza & ND & ND & 0 & ND & ND & 0 & 6.0 & $4.0-11$ & 33 \\
\hline Benzo(k)fluoranthene & Bzf & 15.4 & ND-57 & 33 & 179 & ND-876 & 33 & ND & ND & 0 \\
\hline $\operatorname{Benzo}(a)$ pyrene & Bzp & 156 & ND-645 & 47 & 307 & ND-688 & 60 & 11.0 & $3.0-46$ & 47 \\
\hline $\operatorname{Dibenz}(a, h)$ anthracene & Dbza & 32.4 & ND-104 & 27 & 106 & ND-490 & 40 & 29.6 & $3.0-89$ & 27 \\
\hline $\operatorname{Benzo}(g, h, i)$ perylene & Bzpe & 10.6 & ND-33 & 33 & ND & ND & 0 & 29.6 & ND-219 & 53 \\
\hline Indeno(1,2,3-cd)pyrene & Idpy & 21.6 & ND-88 & 40 & ND & $\mathrm{ND}$ & 0 & 13.4 & ND-47 & 33 \\
\hline Total PAHs & PAHt & 363 & $60-941$ & 100 & 812 & $60-2037$ & 100 & 184 & $57-565$ & 100 \\
\hline
\end{tabular}

ND: not detected.

sulphate and Soxhlet extracted with a mixture of $300 \mathrm{~mL}$ diethyl ether and $100 \mathrm{~mL}$ hexane for $7 \mathrm{~h}$. After concentration through rotary evaporator, $1 \mathrm{~mL}$ of the aliquot was dried at $80^{\circ} \mathrm{C}$ to determine lipid content. The remaining extract was transferred to a $20 \mathrm{~g}$ Florisil-packed dry column $(15 \mathrm{~mm}$ i.d. $\times 30 \mathrm{~mm}$ ), and the solvents were dried by a gentle flow of nitrogen. Organochlorines absorbed on Florisil were eluted with a mixture of $120 \mathrm{~mL}$ acetonitrile and $30 \mathrm{~mL}$ water. The elute was transferred to a separatory funnel containing $600 \mathrm{~mL}$ of water and $100 \mathrm{~mL}$ of hexane. After partitioning, hexane layer was concentrated to $6 \mathrm{~mL}$ and then cleaned with equal volume of concentrated sulphuric acid. The cleaned extract was fractionated by passing through $12 \mathrm{~g}$ of wet Florisil column eluted with hexane $(90 \mathrm{~mL}$; first fraction) and then with $20 \%$ dichloromethane in hexane $(150 \mathrm{~mL}$; second fraction). Each faction was concentrated for analysis in gas chromatograph.

The final extracts were analyzed for 32 congeners of PCBs and the following organochlorine pesticides: isomers of hexachlorocyclohexane $(\mathrm{HCH})(\alpha-, \beta-, \delta$-, and $\gamma$ HCH (lindane)); DDT metabolites, namely, $p, p^{\prime}$-DDT, 1,1dichloro-2,2-bis( $p$-chlorophenyl)ethylene ( $p, p^{\prime}$-DDE), and $p, p^{\prime}$-dichlorodiphenyldichloroethane (DDD); and the cyclodiene insecticides, namely, heptachlor epoxide, dieldrin, and endosulfan and its metabolites $(\alpha-, \beta$-, and endosulfan sulfate). An aliquot $(1 \mu \mathrm{L})$ from the final extract was injected into a Hewlett Packard 5890 series II Gas Chromatograph (GC) equipped with a ${ }^{63} \mathrm{Ni}$ Electron Capture Detector and a splitless injection port. The GC column employed was a DB-608 fused silica capillary column $(30 \mathrm{~m} \times 0.32 \mathrm{~mm} \times$ $0.5 \mu \mathrm{m}$ thickness; J\&W Scientific Inc., Folsom, CA, USA) coated with $35 \%$ phenyl methyl polysiloxane. The column oven temperature was programmed from $180^{\circ} \mathrm{C}$, held for $3 \mathrm{~min}$, then increased to $270^{\circ} \mathrm{C}$ at $10^{\circ} \mathrm{C} / \mathrm{min}$, and held for $20 \mathrm{~min}$. Injector and detector temperatures were set at $250^{\circ} \mathrm{C}$ and $280^{\circ} \mathrm{C}$, respectively. Nitrogen was used as a carrier gas with a column flow rate of $1.5 \mathrm{~mL} / \mathrm{min}$. A mixture of organochlorine pesticides (Dr. Ehrenstorfer, Germany) and a mixture of $32 \mathrm{PCB}$ congeners (AccuStandard, USA) were used as standards. The concentrations of the individual compounds were quantified from the peak area of the sample to that of the corresponding external standard. Recoveries of the compounds from fortified samples $(100 \mathrm{ng} / \mathrm{mL})$ ranged from $94 \%$ to $103 \%$ and from $92 \%$ to $110 \%$ for OCPs and PCBs, respectively. Results are not corrected for per cent recovery. Analyses were run in batches of ten samples plus four quality controls (QCs) including one reagent blank, one matrix blank, one QC check sample, and one random sample in duplicate. The minimum detection limits for all the compounds analyzed were from 1 to $3 \mathrm{ng} / \mathrm{g}$ wet weight.

2.4. Statistical Analysis. Due to skewed distribution, organochlorine residue concentrations were log transformed to satisfy the homogeneity of variance assumption of analysis of variance (ANOVA). For the purpose of analysis, samples below the detection value were given one-half the detection limit before the comparison of the means. Means for each contaminant were compared using one-way ANOVA when at least $50 \%$ of the samples contained detectable concentrations. The probability level determining significance was $P<$ 0.05 for all statistical tests. When significant differences were observed among the means, the Bonferroni multiple comparisons test was applied to determine the levels of significance. All statistical calculations were performed using statistical software SPSS student version 17.

\section{Results}

Residues of PAHs were found in all the 45 tissue samples belonging to 15 vultures. Out of 15 PAHs tested, 11 were detected in one or more tissues analyzed. Among the lower molecular weight representatives, naphthalene exhibited the highest mean concentration to $\sum$ PAHs (29-180 ng/g wet wt). The high molecular weight representatives were the most frequently detected, PAHs (Table 2). Phenanthrene, anthracene, 
TABLE 3: Organochlorine residues (ng/g) detected in vultures in India.

\begin{tabular}{|c|c|c|c|c|c|c|c|c|c|}
\hline \multirow{3}{*}{ Contaminants } & \multicolumn{3}{|c|}{ Brain $(n=15)$} & \multicolumn{3}{|c|}{ Liver $(n=15)$} & \multicolumn{3}{|c|}{ Muscle $(n=15)$} \\
\hline & \multicolumn{3}{|c|}{ Lipid weight (\%) 10} & \multicolumn{3}{|c|}{ Lipid weight (\%) 16} & \multicolumn{3}{|c|}{ Lipid weight (\%) 11} \\
\hline & Mean & Range & $\%$ & Mean & Range & $\%$ & Mean & Range & $\%$ \\
\hline$\alpha-\mathrm{HCH}$ & 6.9 & ND-43.9 & 31 & $74.8^{*}$ & ND-414 & 46 & 22.9 & ND-282 & 38 \\
\hline$\beta-\mathrm{HCH}$ & 103 & ND-788 & 85 & 306 & $3.6-1565$ & 100 & 163 & $3.2-1465$ & 100 \\
\hline$\gamma-\mathrm{HCH}$ & 5.7 & ND-18.1 & 69 & $138^{*}$ & ND-696 & 92 & 25.5 & ND-168 & 77 \\
\hline$\delta-\mathrm{HCH}$ & 11.3 & ND-43.3 & 15 & 45.6 & ND-380 & 23 & 9.3 & ND-76.5 & 38 \\
\hline$\sum \mathrm{HCH}$ & 128 & $1.9-893$ & 100 & 565 & $3.6-3054$ & 100 & 220 & $3.9-1991$ & 100 \\
\hline$p, p^{\prime}-\mathrm{DDE}$ & 12.2 & ND-68.9 & 77 & 117 & $4.3-599$ & 100 & 86.1 & ND-487 & 85 \\
\hline$p, p^{\prime}-\mathrm{DDD}$ & 8.2 & ND-38.9 & 31 & 79.1 & ND-217 & 46 & 85.5 & ND-461 & 38 \\
\hline$p, p^{\prime}-\mathrm{DDT}$ & 3.1 & ND-9.3 & 54 & 52.3 & ND-263 & 69 & 12.2 & ND-83.4 & 62 \\
\hline$\sum \mathrm{DDT}$ & 20.3 & ND-117 & 92 & 248 & $4.3-1079$ & 100 & 184 & DBL-1031 & 85 \\
\hline Heptachlor epoxide & 21.2 & ND-93.5 & 38 & $150^{*}$ & ND-1206 & 69 & 10.9 & ND-29.9 & 54 \\
\hline Dieldrin & 7.3 & ND-43.1 & 23 & 23.2 & ND-223 & 54 & 6.6 & ND-45.6 & 46 \\
\hline$\sum$ Endosulfan & 9.55 & ND-56.7 & 15 & 96.1 & ND-450 & 31 & 87.5 & ND-384 & 23 \\
\hline$\sum \mathrm{OCPs}$ & 187 & $3.9-991$ & 100 & $1083^{*}$ & $3.6-5836$ & 100 & 509 & $3.2-2089$ & 100 \\
\hline$\sum$ PCBs & 359 & $30-1346$ & 100 & 825 & $40-5790$ & 100 & 646 & $46.8-4063$ & 100 \\
\hline
\end{tabular}

Range: (minimum-maximum), ND: below detection limit, \%: percentage of sample with quantifiable level, and ${ }^{*}$ : mean was significantly different from other tissues $(P<0.05)$.

chrysene, and benzo(b)fluoranthene were not detected in any of the tissues analyzed. The mean concentration of $\sum \mathrm{PAHs}$ found in brain, liver, and muscle tissues were $363 \mathrm{ng} / \mathrm{g}$, $812 \mathrm{ng} / \mathrm{g}$, and $184 \mathrm{ng} / \mathrm{g}$, wet weight, respectively. Among the tissues analyzed, liver had higher level of most of the PAHs tested, as biotransformation takes place in liver. While the total PAHs levels in brain, liver, and muscle were 176.6, 139.4, and $91.8 \mathrm{ng} / \mathrm{g}$, respectively, during 2005 , by 2007 , the levels went up almost two-fold (Figure 1). However, there was no significant difference observed among the years $(P>0.05)$.

Organochlorine pesticide residues and PCB residues were detected in all the tissues of vultures (Table 3 ). The mean concentration of organochlorine residues in the liver tissues of White-backed Vulture was higher than that in the other tissues $(P<0.05)$. Among the various OCPs analyzed, $\mathrm{HCH}$ and its isomers contributed maximum to the total OCPs. The level of mean $\sum \mathrm{HCH}$ among the tissues ranged from 128 to $565 \mathrm{ng} / \mathrm{g}$. $\beta$-isomer of $\mathrm{HCH}$ accounted for the major burden of total $\mathrm{HCH}$. Mean $\sum \mathrm{DDT}$ among tissues ranged from 20.3 to $248 \mathrm{ng} / \mathrm{g}$. Among the metabolites of DDT, $p, p^{\prime}-$ $\mathrm{DDE}$ was the most frequently detected metabolite. Its mean concentration ranged between $12.2 \mathrm{ng} / \mathrm{g}$ and $117 \mathrm{ng} / \mathrm{g}$. The concentrations of cyclodiene insecticides were less than the other organochlorine residues. Total PCB residues in brain, liver, and muscle samples ranged from 30 to $1346 \mathrm{ng} / \mathrm{g}, 40$ to $5790 \mathrm{ng} / \mathrm{g}$, and 46.8 to $4063 \mathrm{ng} / \mathrm{g}$, respectively. Similar to organochlorine pesticides, high accumulation of PCBs was found in liver tissues.

To know the temporal variation in the levels of PAHs, organochlorine pesticides, and PCBs, residue data collected between 2005 and 2007 were compared. There was no significant difference observed among the years. Hence, these concentrations could be treated as baseline values (Figure 1). Sex-wise variation was not analyzed due to small sample size.

\section{Discussion}

Analyses of results suggest that White-backed Vultures are exposed to varying levels of PAHs, and other organochlorine chemicals. It is to be noted that data on the levels of PAHs, PCBs, and pesticides in birds and with special reference to vultures in India are scarce. The absence of comparable data on residue levels in the tissues of the same species rendered direct analogies, for the majority of toxicants included in this study, extremely difficult. Therefore, this investigation was initiated to document contamination levels in vultures in India and create a database for future reference. Values cited from the literature on the levels of contaminants in tissues/serum/eggs samples of birds are not intended for direct comparisons but to provide an indication of contamination.

4.1. PAHs Contamination. To the best of our knowledge, this is the first report on PAHs levels in brain, liver, and muscle tissues of White-backed Vultures in India. Although PAHs are not commonly detected in the tissues of birds from noncontaminated sites, they tend to be present in very small amounts [26]. In the present study, detectable concentration of total PAHs was found in the tissues of White-backed Vulture. There are reports on the levels of PAHs in feather and plasma samples of seabirds which had fallen victims to oil spills [25] in the east coast of England. Studies on seabirds reported high concentration of PAHs accumulation through food chain [4, 27]. The source of PAHs in the tissue of birds studied in the present investigation could be through food chain accumulation. It is to be noted that Ahmedabad is one of the most industrialized cities in Gujarat, with various industries including refining operations, industrial and municipal discharges, waste oil disposal, and urban runoff. 


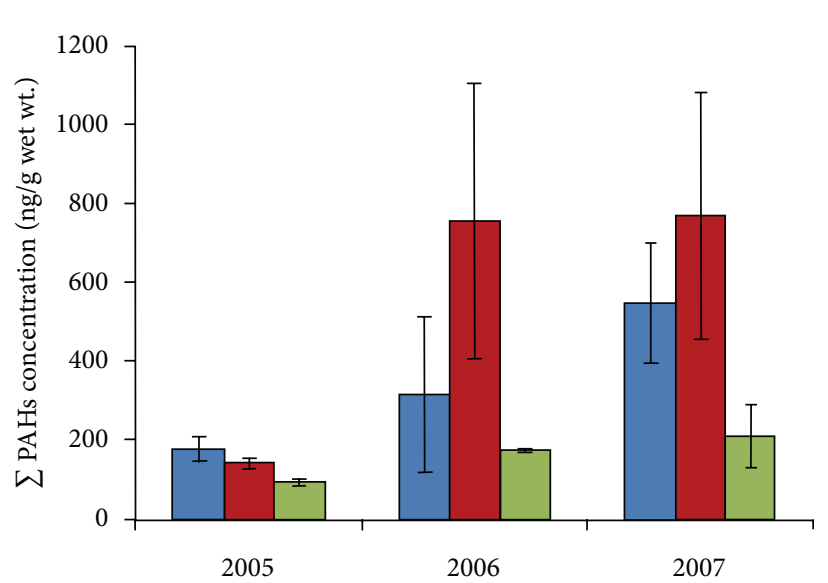

(a)

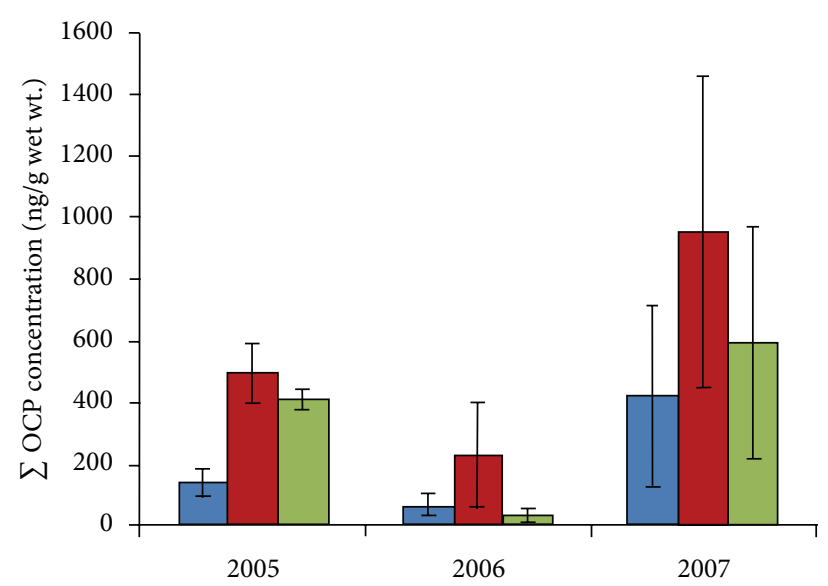

(b)

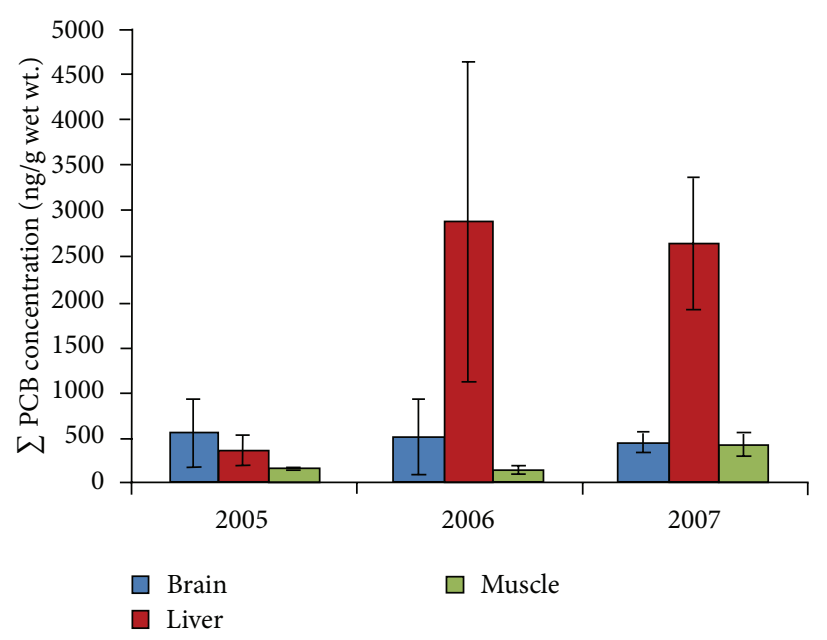

(c)

FIGURE 1: Variation in concentration of OCPs, PCBs, and PAHs in brain, liver, and muscle tissues of White-backed Vulture from India.

Ingestion of oil either through food or during preening is considered to be the primary source of PAHs to birds [28].

The total PAH concentration reported in the tissues in the present study are higher than the concentration reported in the whole body (120-160 ng/g) in Lesser Scaup (Aythya affinis), collected from Indiana Harbor Canal, USA [4], and wild juvenile Common Eider Ducks (Somateria mollissima) from the Baltic Sea [7]. Although PAH levels recorded in the present study do not reflect the extent of exposure to PAHs, the residues of parent $\mathrm{PAH}$ indicate that the sampling sites are contaminated with PAHs. Similar observations were reported in bird tissues from contaminated sites [4, 29]. Levels of PAHs in the present study are an order of magnitude lower than those reported in Common Guillemots Uria aalge which had got exposed to oil spill on the east coast of England during 2001-2002 [25].

Administration of benzo(a)pyrene to pigeon for 3-4 months had resulted in the formation of arterial lesions and ovarian abnormalities and eventually turned the females infertile, but apparently there were no effects on males
[30]. Biomagnification of PAHs through food chain has been linked to reproductive impairment in many species of predatory birds worldwide [31]. It has been observed that the concentrations of total PAHs are considerably higher in brain than those in other tissues. Generally the contamination load in birds is related to their content and composition of prey, age, and residence time at contaminated sites [32]. Similar observations were noted in aquatic bird species, namely, Lesser Scaup, Redheads, Silver Gulls, Australian Pelicans $[4,27]$ and Common Guillemots [25]. Benzo(a)pyrene and chrysene have been shown to induce embryotoxicity in Mallards Anas platyrhynchos. Topical applications of eggs with benzo(a)pyrene $\left(0.0336 \times 10^{-3} \mathrm{ug} / \mathrm{g}\right)$ and chrysene $\left(0.273 \times 10^{-3} \mathrm{ug} / \mathrm{g}\right)$ had caused deformities and growth reductions, and in doses of $2.0 \mathrm{mg} / \mathrm{kg} / \mathrm{egg}$, benzo(a)pyrene $/ \mathrm{g}$ and $0.273 \times 10^{-3}$ ug of chrysene/g had caused deformities, growth reductions, and mortality [33, 34]. In doses of $2 \mathrm{mg} / \mathrm{kg} / \mathrm{egg}$, benzo(a)pyrene and indeno(1,2,3-cd)pyrene severely decreased survival, while chrysene caused a significant increase in lesions in embryos in Common Eider, 
Domestic Chicken, Turkey, and Duck [35]. Toxicity can vary with the amount and types of individual contaminants in the tissues of birds [36].

Although levels of PAHs are not likely to create lethal effect, sublethal effects such as gastrointestinal irritation, pneumonia, damage to red blood cells, immune system suppression, hormonal imbalance, impaired reproduction, and reduced growth have been reported by Albers [37] in oil ingested birds.

4.2. Organochlorine Pesticides. Organochlorine pesticide residues were the maximum in the liver tissues of vultures (Table 3). OCPs documented in the tissues of White-backed Vulture were lower than the levels reported in tissues of White-backed Vulture collected from the same location between 1999 and 2003 [38]. The total HCH concentrations reported in the present study are concordant with the results reported in blood plasma of three species of vulture from India [18] and lower than the levels reported in the same species collected from the urban area of Lucknow, India, during 1980 [39]. It indicates the declining trend in the environmental residue level of the compound in the Indian environment. Although the levels are not indicative of any ill effects, they are higher than the levels reported in South African Vulture [40]. Previous studies in Indian biota have also reported high levels of $\mathrm{HCH}[18,20,38]$. There is also substantial use of $\gamma$ - $\mathrm{HCH}$ in India for agricultural purpose, which is a matter of concern.

It is interesting to note that the DDE values detected in the present study are several folds lower than the values reported in the same species in Lucknow, India [39]. However, it may be noted that the levels of DDT and its metabolites detected in the present study are concordant with the results reported in tissues of the same species collected from different locations in India [38] and higher than the levels reported in the blood plasma of three species of vultures from India [18]. Although the levels of $p, p^{\prime}$-DDT, $p, p^{\prime}$-DDD, and $p, p^{\prime}$ DDE detected in the present study were well below the levels $(25 \mu \mathrm{g} / \mathrm{g}$ of DDT) reported to be responsible for mortality of birds [41], they were higher than the levels reported in blood and tissues samples of South African White-backed Vulture [40] and serum samples of Egyptian Vulture [42]. Mean levels of total organochlorine pesticides analyzed in the present study were considerably higher than the levels reported in Cinereous Vulture (14.76 ng/g wet wt) and Eurasian Vulture (19.98 ng/g wet wt) [43]. The present study values are also far below the concentrations in eggs that were correlated with toxic effects in different species of birds $(5 \mu \mathrm{g} / \mathrm{g})$. Higher concentration of $p, p^{\prime}$-DDE in the tissues of vulture showed recent input, persistent and lipophilic nature in the environment.

The most toxic cyclodiene compound, dieldrin, was recorded in all the tissues of vulture collected from Ahmedabad. All these levels are well below the levels expected to create harmful effect to avian population [44]. However, it may be noted that the "effects range-low" (ER-L) value (i.e., the contamination level above whose adverse biological effects are occasionally observed) is listed as $0.02 \mu \mathrm{g} / \mathrm{kg}$ for dieldrin [45]. Another cyclodiene pesticide, heptachlor epoxide, a metabolite of heptachlor, was also detected in the tissues. Residues of $0.10-0.73 \mu \mathrm{g} / \mathrm{g}$ have been reported in Black-crowned Night-Heron [46] and 0.001 to $0.042 \mu \mathrm{g} / \mathrm{g}$ in South African Vulture [40]. The levels recorded in the present study are higher than the $\mathrm{LC}_{50}$ values reported for birds [47]. The experimental study by Henny et al. [48] concluded that residues greater than $1.5 \mathrm{ppm}$ were most definitely associated with decreased reproduction rates in avian species. The birds included in the study had residues of heptachlor epoxide in one or more tissues and are to be viewed with concern.

4.3. PCBs. The variation in contamination levels among species may be due to different feeding habitats and behaviors. The observed mean PCB concentrations were lower than those reported in birds in other countries [46]. Considerably high concentrations of total PCBs in vultures of Gujarat could be attributed to contamination due to industrial operations. Biotransformations are unlikely for the PCBs, as the majority of PCB congeners constituting the total PCB are recalcitrant in birds [49]. This pattern of high accumulation of PCB congener in avian species is contributed mainly through their food [1]. The total PCB concentration recorded in various tissues of vultures in this study is twenty fold to two hundredfold higher than the concentration reported in Black-winged Kite (29 ppb) [50], while it is two-fold higher than the levels (1600-2100 ng/g) which had shown reproductive impairment in Black Cormorant Phalacrocorax carbo sinensis [51] and almost similar to the levels (3600$7300 \mathrm{ng} / \mathrm{g}$ ) reported to have caused tissue malformation in Double-crested Cormorant Phalacrocorax auritus [52].

The total PCB concentration in tissues of vultures in the present study is greater than the concentration reported in the whole body concentration of total PCB in Crested Kingfisher (160 ppb), the resident bird collected from south India, and comparable with the levels reported in a shortdistance migrant, White-cheeked Tern (430-4400 ppb). It is also reported that the concentrations of PCBs in resident birds of India were less than those reported from other parts of the world. However, there has been a sign of increase in PCB concentration in resident birds, and it is assumed that PCB contamination might increase in India in the years to come due to rapid industrialization and development [50]. Additionally, unlike OCPs, PCB usage is largely related to industrial activities; therefore, higher contamination of PCBs is documented in industrial areas. Although the tissuewise variation was not significant in the present study, liver tissues showed higher load of total PCBs. Individual PCB congeners exhibit different physicochemical properties resulting in different profile of the environmental distribution and toxicity [53].

Biotransformation may also result in lower concentrations in the liver compared with fat as the liver is an active site of biotransformation. This may occur with $\mathrm{HCH}$, as reported by Moisey et al. [54], in seabirds that are known to readily biotransform both $\alpha$ - and $\gamma$ - $\mathrm{HCH}$, but this would seem unlikely for the PCBs [49]. Hence, it may be expected that the concentration of PCBs in liver can be at higher levels. The total PCB residues in various tissues of vultures 
were within the range (300 to $180,000 \mathrm{ppb}$ ) reported in Little Egrets Egretta garzetta which was found dead or dying in Tokyo Bay [55]. Generally, PCBs are present at higher levels than DDE, and high concentrations of these compounds occurred in biota in water adjacent to the cities [56]. It can be suggested that the presence of petroleum-based industries in Ahmedabad might have accounted for PCB input into the environment.

\section{Conclusion}

This is the first study that documented the concentrations of PAHs, OCPs, and PCBs among various tissues of vultures in India. Among the various tissues analyzed, liver tissue recorded the maximum concentration of PAHs and other pollutants. It can be suggested that the petroleum-based industries located in Ahmedabad might have contributed to the excessive exposure of PAHs and PCBs in this species. Although the birds collected were victims to kite injuries, the concentration reported in the present study may cause sublethal effects. Although, the PCBs detected in tissues of vulture are not likely to have an impact on the demographic performance of the population as a whole, the residues may reach levels causing decreased reproduction or survival in the future, particularly when combined with other nonanthropogenic stressors such as food scarcity. In addition, the vultures normally would have more exposure to the contaminants due to their position in the food chain. Incidentally, none of the tissues are free from contaminants. Although a few experimental studies have shown the effects of PAHs on bird behavior, field assessments are invariably confounded by ecological differences between contaminated and uncontaminated sites. This study recommends continuous monitoring of persistent environmental contaminants not only in vultures but also in other species of birds.

\section{Conflict of Interests}

The authors declare that there is no conflict of interests.

\section{Acknowledgments}

The authors thank Gujarat State Forest Department, Mr. Rahul Shaghal, and Mr. Kartik Sastri, Ahmedabad, for their support, and they also thank the Director of Sálim Centre for Ornithology and Natural History, Coimbatore, for financial assistance.

\section{References}

[1] M. A. Mora, "Congener-specific polychlorinated biphenyl patterns in eggs of aquatic birds from the Lower Laguna Madre, Texas," Environmental Toxicology and Chemistry, vol. 15, no. 6, pp. 1003-1010, 1996.

[2] R. Guitart, M. Torra, S. Cerradelo, P. Puig-Casado, R. Mateo, and J. To-Figueras, " $\mathrm{Pb}, \mathrm{Cd}, \mathrm{As}$, and Se concentrations in livers of dead wild birds from the Ebro Delta, Spain," Bulletin of Environmental Contamination and Toxicology, vol. 52, no. 4, pp. 523-529, 1994.
[3] W. Henriques, R. D. Jeffers, T. E. Lacher, and R. J. Kendall, "Agrochemical use on banana plantations in Latin America: perspectives on ecological risk," Environmental Toxicology and Chemistry, vol. 16, no. 1, pp. 91-99, 1997.

[4] T. W. Custer, C. M. Custer, R. K. Hines, and D. W. Sparks, “Trace elements, organochlorines, polycyclic aromatic hydrocarbons, dioxins, and furans in lesser scaup wintering on the Indiana Harbor Canal," Environmental Pollution, vol. 110, no. 3, pp. 469$482,2000$.

[5] D. H. White, K. A. King, C. A. Mitchell, and B. M. Mulhern, "Trace elements in sediments, water, and American coots (Fulica americana) at a coal-fired power plant in Texas, 19791982," Bulletin of Environmental Contamination and Toxicology, vol. 36, no. 3, pp. 376-383, 1986.

[6] P. C. van Metre, B. J. Mahler, and E. T. Furlong, "Urban sprawl leaves its $\mathrm{PAH}$ signature," Environmental Science and Technology, vol. 34, no. 19, pp. 4064-4070, 2000.

[7] C. Naf, D. Broman, and B. Brunstrom, "Distribution and metabolism of polycyclic aromatic hydrocarbons (PAHs) injected into eggs of chicken (Gallus domesticus) and common eider duck (Somateria mollissima)," Environmental Toxicology and Chemistry, vol. 11, no. 11, pp. 1653-1660, 1992.

[8] P. Mineau, G. A. Fox, R. J. Norstrom, D. V. Weseloh, D. J. Hattlett, and J. A. Ellenton, "Using the herring gull to monitor levels and effects of organochlorine contamination in the Canadian Great lakes," in Toxic Contaminants in the Great Lakes, J. O. Nriagu and M. S. Simmons, Eds., pp. 425-452, John Wiley \& Sons, New York, NY, USA, 1984.

[9] K. Oxynos, J. Schmitzer, and A. Kettrup, "Herring gull eggs as bioindicators for chlorinated hydrocarbons (contribution to the German federal environmental specimen bank)," Science of the Total Environment, vol. 139-140, pp. 387-398, 1993.

[10] J. W. Choi, M. Matsuda, M. Kawano, B. Y. Min, and T. Wakimoto, "Accumulation profiles of persistent organochlorines in waterbirds from an estuary in Korea," Archives of Environmental Contamination and Toxicology, vol. 41, no. 3, pp. 353-363, 2001.

[11] S. L. Porter, "Pesticide poisoning in birds of prey," in Raptor Biomedicine, T. P. Redig, J. E. Cooper, J. D. Remple, and B. Hunter, Eds., pp. 329-345, University of Minnesota Press, Minneapolis, Minn, USA, 1993.

[12] A. Kumari, R. K. Slnha, K. Gopal, and K. Prasad, "Dietary intake of persistent organochlorine residues through gangetic fishes in India," International Journal of Ecology and Environmental Sciences, vol. 27, no. 2, pp. 117-120, 2001.

[13] D. Houston, "Indian white-backed vulture Gyps bengalensis," in Conservation Studies on Raptors, I. Newton and R. D. Chancellor, Eds., Technical Publication No. 5, pp. 465-466, International Council for Bird Preservation, HPPWD, Cambridge, UK, 2009/2010, http://hppwd.gov.in/SH\%20\&\%20MDRs.htm.

[14] V. Prakash, D. J. Pain, A. A. Cunningham et al., "Catastrophic collapse of indian white-backed Gyps bengalensis and longbilled Gyps indicus vulture populations," Biological Conservation, vol. 109, no. 3, pp. 381-390, 2003.

[15] A. A. Cunningham, V. Prakash, D. Pain et al., "Indian vultures: victims of an infectious disease epidemic?" Animal Conservation, vol. 6, no. 3, pp. 189-197, 2003.

[16] D. J. Pain, A. A. Cunningham, P. F. Donald et al., "Causes and effects of temporospatial declines of Gyps vultures in Asia," Conservation Biology, vol. 17, no. 3, pp. 661-671, 2003.

[17] J. L. Oaks, M. Gilbert, M. Z. Virani et al., "Diclofenac residues as the cause of vulture population decline in Pakistan," Nature, vol. 427, no. 6975, pp. 630-633, 2004. 
[18] V. Dhananjayan, S. Muralidharan, and P. Jayanthi, "Distribution of persistent organochlorine chemical residues in blood plasma of three species of vultures from India," Environmental Monitoring and Assessment, vol. 173, no. 1-4, pp. 803-811, 2011.

[19] S. Ostrowski and M. Shobrak, "Pesticide poisoning in a freeranging lappet-faced vulture (Torgos tracheliotus)," Veterinary Record, vol. 149, no. 13, pp. 396-397, 2001.

[20] V. Dhananjayan and S. Muralidharan, "Levels of organochlorine pesticide residues in blood plasma of various species of birds from India," Bulletin of Environmental Contamination and Toxicology, vol. 85, no. 2, pp. 129-136, 2010.

[21] V. Dhananjayan, "Accumulation pattern of persistent organochlorine pesticides in liver tissues of various species of birds from India," Environmental Science and Pollution Research, vol. 20, no. 5, pp. 3149-3156, 2013.

[22] V. Dhananjayan, "Accumulation pattern and distribution of polycyclic aromatic hydrocarbons (PAHs) in liver tissues of seven species of birds from Ahmedabad, India, during 20052007," Environmental Science and Pollution Research, vol. 20, no. 5, pp. 3414-3422, 2013.

[23] Express News Service, "Gujarat records steep decline in vulture population," 2009, http://www.indianexpress.com/news/ gujarat-records-steep-decline-in-vulture-pop/426629/.

[24] J. Hu, G. Zhang, and C. Q. Liu, "Pilot study of polycyclic aromatic hydrocarbons in surface soils of Guiyang City, People's Republic of China," Bulletin of Environmental Contamination and Toxicology, vol. 76, no. 1, pp. 80-89, 2006.

[25] G. M. Troisi, S. Bexton, and I. Robinson, "Polyaromatic hydrocarbon and PAH metabolite burdens in oiled common guillemots (Uria aalge) stranded on the East Coast of England (2001-2002)," Environmental Science and Technology, vol. 40, no. 24, pp. 7938-7943, 2006.

[26] R. J. Hall and N. C. Coon, "Interpreting residues of petroleum hydrocarbons in wildlife tissues," Biological Report-US Fish \& Wildlife Service, vol. 88, no. 15, article 8, 1988.

[27] E. Aas, J. Beyer, and A. GoksØyr, "Fixed wavelength fluorescence (FF) of bile as a monitoring tool for polyaromatic hydrocarbon exposure in fish: an evaluation of compound specificity, inner filter effect and signal interpretation," Biomarkers, vol. 5, no. 1, pp. 9-23, 2000.

[28] S. Taniguchi, R. Montone, M. Bicego, and J. Sericano, "Chlorinated pesticides, PCBs and PAHs in bubbler of sea birds from King George Island, Antartica," Society of Environmental Toxicology and Chemistry, vol. 24, pp. 25-56, 2003.

[29] T. W. Custer, C. M. Custer, K. Dickerson, K. Allen, M. J. Melancon, and L. J. Schmidt, "Polycyclic aromatic hydrocarbons, aliphatic hydrocarbons, trace elements, and monooxygenase activity in birds nesting on the North Platte River, Casper, Wyoming, USA," Environmental Toxicology and Chemistry, vol. 20, no. 3, pp. 624-631, 2001.

[30] J. L. Hough, M. B. Baird, G. T. Sfeir, C. S. Pacini, D. Darrow, and C. Wheelock, "Benzo(a)pyrene enhances atherosclerosis in White Carneau and Show Racer pigeons," Arteriosclerosis and Thrombosis, vol. 13, no. 12, pp. 1721-1727, 1993.

[31] S. B. de Luca-Abbott, B. S. F. Wong, D. B. Peakall et al., "Review of effects of water pollution on the breeding success of waterbirds, with particular reference to ardeids in Hong Kong," Ecotoxicology, vol. 10, no. 6, pp. 327-349, 2001.

[32] J. Struger and D. V. Weseloh, "Great lakes Caspian Terns: egg contaminants and biological implications," Colonial Water Birds, vol. 8, pp. 142-149, 1985.
[33] D. J. Hoffman and M. L. Gay, "Embryotoxic effects of benzo[a]pyrene, chrysene, and 7,12-dimethylbenz[a]anthracene in petroleum hydrocarbon mixtures in mallard ducks," Journal of Toxicology and Environmental Health, vol. 7, no. 5, pp. 775-787, 1981.

[34] R. Eisler, Polycyclic Aromatic Hydrocarbon Hazards to Fish, Wildlife, and Invertebrates: A Synoptic Review, US Department of the Interior, US Fish and Wildlife Service, 1987.

[35] B. Brunstrom, D. Broman, and C. Naf, "Embryotoxicity of polycyclic aromatic hydrocarbons (PAHs) in three domestic avian species, and of PAHs and coplanar polychlorinated biphenyls (PCBs) in the common eider," Environmental Pollution, vol. 67, no. 2, pp. 133-143, 1990.

[36] P. Ramirez, "Environmental contaminants in the Aquatic bird food chain of an oil refinery wastewater pond," U.S. Fish and Wildlife Service, Region 6, Environmental Contaminants Report, pp. 1-15, 1997.

[37] P. H. Albers, "Petroleum and individual aromatic hydrocarbons," in Handbook of Ecotoxicology, D. J. Hoffman, B. A. Rattner, G. A. Burton, and J. Cairns Jr., Eds., pp. 330-355, Lewis Publishers, Boca Raton, Fla, USA, 1995.

[38] S. Muralidharan, V. Dhananjayan, R. Risebrough, V. Prakash, R. Jayakumar, and P. H. Bloom, "Persistent organochlorine pesticide residues in tissues and eggs of white-backed vulture, Gyps bengalensis from different locations in India," Bulletin of Environmental Contamination and Toxicology, vol. 81, no. 6, pp. 561-565, 2008.

[39] B. S. Kaphalia, M. M. Husain, T. D. Seth, A. Kumar, and C. R. Murti, "Organochlorine pesticide residues in some Indian wild birds," Pesticide Monitoring Journal, vol. 15, no. 1, pp. 9-13, 1981.

[40] E. van Wyk, H. Bouwman, H. van der Bank, G. H. Verdoorn, and D. Hofmann, "Persistent organochlorine pesticides detected in blood and tissue samples of vultures from different localities in South Africa," Comparative Biochemistry and Physiology C, vol. 129, no. 3, pp. 243-264, 2001.

[41] W. H. Stickel, L. F. Stickel, and F. B. Coon, "DDE and DDD residues correlated with mortality of experimental birds," in Pesticide Symposia, W. B. Deichmann, Ed., pp. 287-294, Halo Associates, Miami, Fla, USA, 1970.

[42] B. Gómara, L. Ramos, L. Gangoso, J. A. Donázar, and M. J. González, "Levels of polychlorinated biphenyls and organochlorine pesticides in serum samples of Egyptian Vulture (Neophron percnopterus) from Spain," Chemosphere, vol. 55, no. 4, pp. 577-583, 2004.

[43] V. Goutner, T. Skartsi, I. K. Konstantinou et al., "Organochlorine residues in blood of cinereous vultures and Eurasian griffon vultures in a Northeastern Mediterranean area of nature conservation," Environmental Monitoring and Assessment, vol. 183, no. 1-4, pp. 259-271, 2011.

[44] G. H. Heinz and R. W. Johnson, "Diagnostic brain residues of dieldrin: some new insights," in Avian and Mammalian Wildlife Toxicology, D. W. Lamb and E. E. Kenaga, Eds., ASTM STP 757, pp. 72-92, American Society for Testing and Materials, Philadelphia, Pa, USA, 1981, Chemosphere, vol. 53, pp. 173-182, 1981.

[45] E. R. Long, D. D. Macdonald, S. L. Smith, and F. D. Calder, "Incidence of adverse biological effects within ranges of chemical concentrations in marine and estuarine sediments," Environmental Management, vol. 19, no. 1, pp. 81-97, 1995.

[46] G. H. Heinz, T. C. Erdman, S. D. Haseltine, and C. Stafford, "Contaminant levels in colonial waterbirds from Green Bay 
and Lake Michigan, 1975-80," Environmental Monitoring and Assessment, vol. 5, no. 3, pp. 223-236, 1985.

[47] R. G. Heath, J. W. Spann, E. F. Hill, and J. F. Kreitzer, Comparative Dietary Toxicities of Pesticides to Birds, US Fish and Wildlife Services, Washington, DC, USA, 1983.

[48] C. J. Henny, L. J. Blus, and C. J. Stafford, "Effects of heptachlor on American kestrels in the Columbia basin, Oregon," Journal of Wildlife Management, vol. 47, no. 4, pp. 1080-1087, 1983.

[49] K. G. Drouillard, K. J. Fernie, J. E. Smits, G. R. Bortolotti, D. M. Bird, and R. J. Norstrom, "Bioaccumulation and toxicokinetics of 42 polychlorinated biphenyl congeners in American kestrels (Falco sparverius)," Environmental Toxicology and Chemistry, vol. 20, no. 11, pp. 2514-2522, 2001.

[50] S. Tanabe, K. Senthilkumar, K. Kannan, and A. N. Subramanian, "Accumulation features of polychlorinated biphenyls and organochlorine pesticides in resident and migratory birds from South India," Archives of Environmental Contamination and Toxicology, vol. 34, no. 4, pp. 387-397, 1998.

[51] S. Dirksen, T. J. Boudewijn, L. K. Slager, R. G. Mes, M. J. M. van Schaick, and P. de Voogt, "Reduced breeding success of cormorants (Phalacrocorax carbo sinensis) in relation to persistent organochlorine pollution of aquatic habitats in The Netherlands," Environmental Pollution, vol. 88, no. 2, pp. 119132, 1995.

[52] N. Yamashita, S. Tanabe, J. P. Ludwig, H. Kurita, M. E. Ludwig, and R. Tatsukawa, "Embryonic abnormalities and organochlorine contamination in double-crested cormorants (Phalacrocorax auritus) and Caspian terns (Hydroprogne caspia) from the upper Great Lakes in 1988," Environmental Pollution, vol. 79, no. 2, pp. 163-173, 1993.

[53] J. P. Giesy and K. Kannan, "Dioxin-like and non-dioxin-like toxic effects of polychlorinated biphenyls (PCBs): implications for risk assessment," Critical Reviews in Toxicology, vol. 28, no. 6, pp. 511-569, 1998.

[54] J. Moisey, A. T. Fisk, K. A. Hobson, and R. J. Norstrom, "Hexachlorocyclohexane $(\mathrm{HCH})$ isomers and chiral signatures of $\alpha-\mathrm{HCH}$ in the arctic marine food web of the Northwater Polynya," Environmental Science and Technology, vol. 35, no. 10, pp. 1920-1927, 2001.

[55] M. Doguchi, "Chlorinated hydrocarbons in the environment in the Kanto Plain and Tokyo Bay, as reflected in fishes, birds and man," in New Methods in Environmental Chemistry and Toxicology, F. Coulston, F. Korte, and M. Goto, Eds., pp. 269289, International Academy Printing Company, Tokyo, Japan, 1973.

[56] H. M. Ohlendorf, R. W. Risebrough, and K. Vermeer, "Exposure of marine birds to environmental pollutants," Wildlife Research Report, US Fish and Wildlife Services, 1978. 

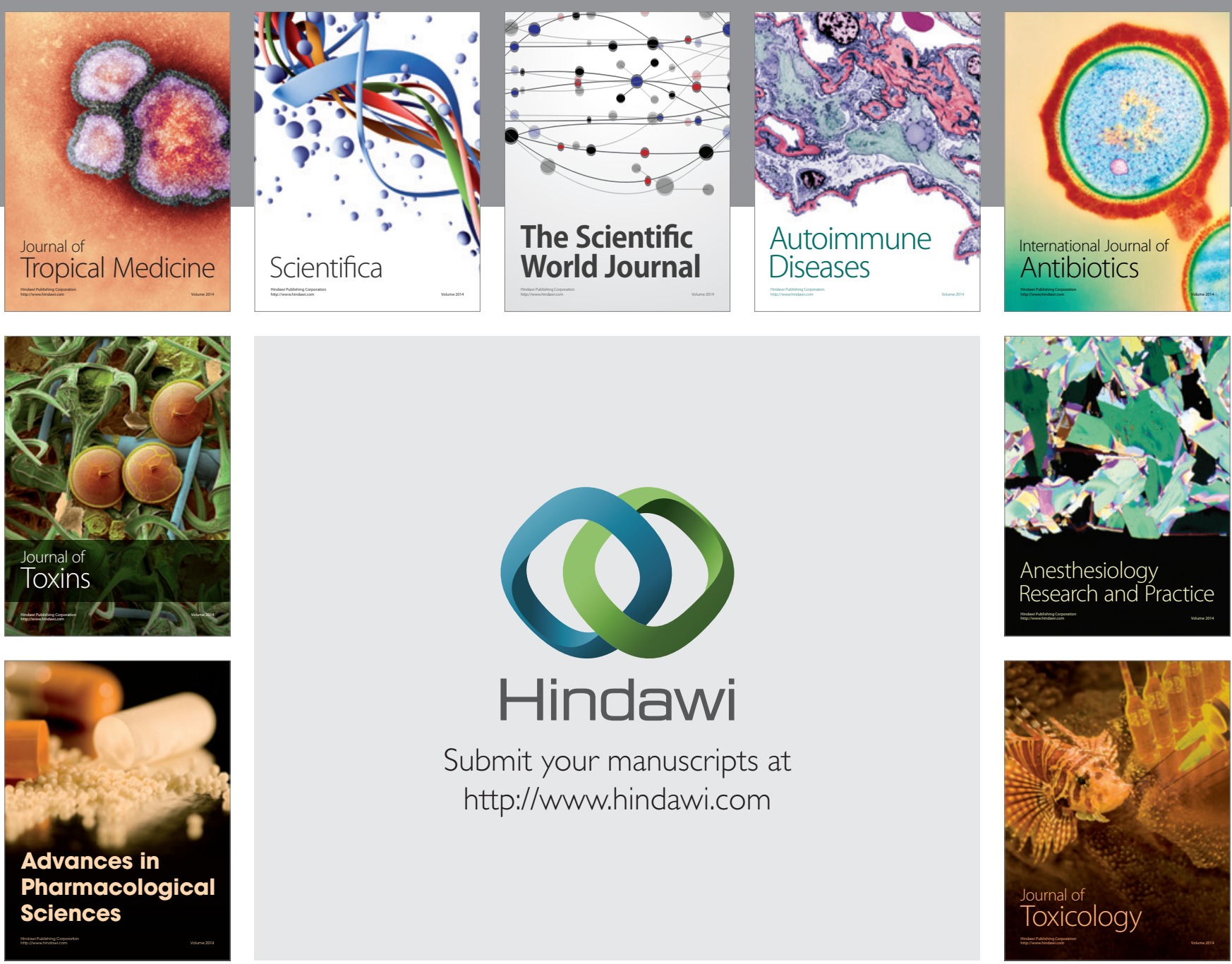

\section{Hindawi}

Submit your manuscripts at

http://www.hindawi.com
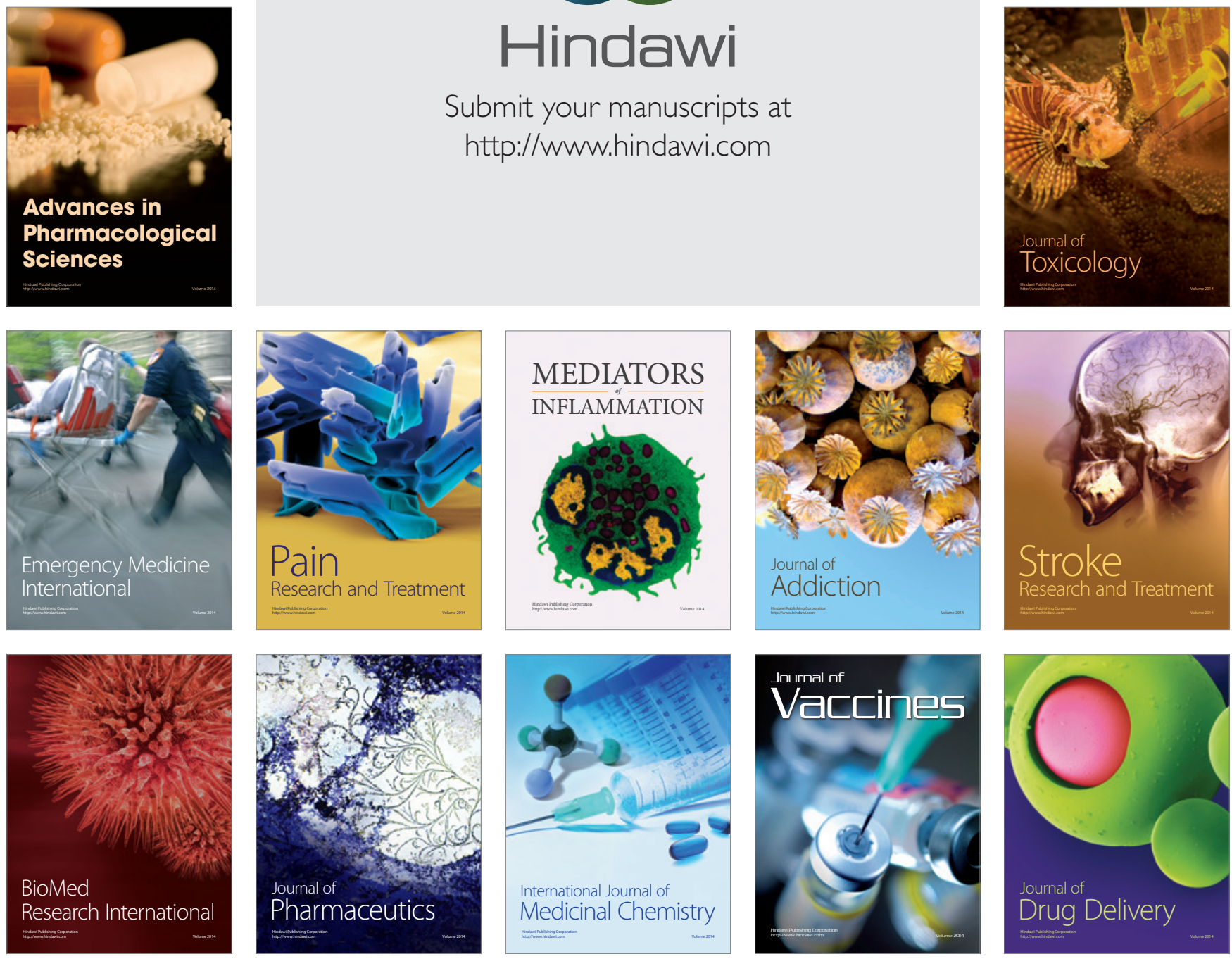